\title{
Growth characteristics and vertical distribution of Triparma laevis (Parmales) during summer in the Oyashio region, western North Pacific
}

\author{
Mutsuo Ichinomiya ${ }^{1, *}$, Miwa Nakamachi $^{2}$, Yugo Shimizu $^{3}$, Akira Kuwata $^{2}$ \\ ${ }^{1}$ Prefectural University of Kumamoto, Tsukide 3-1-100, Higashi, Kumamoto 862-8502, Japan \\ ${ }^{2}$ Tohoku National Fisheries Research Institute, Shinhamacho 3-27-5, Shiogama, Miyagi 985-0001, Japan \\ ${ }^{3}$ National Research Institute of Fisheries Science, Fukuura 2-12-4, Kanazawa, Yokohama 236-8648, Japan
}

\begin{abstract}
The vertical and regional distribution of Triparma laevis (Parmales), a siliceous picosized eukaryotic marine phytoplankton species, was investigated during summer off the south coast of Hokkaido, Japan, in the western North Pacific. Growth characteristics were also studied in the laboratory using a recently isolated culture strain. T. laevis was abundant in the subsurface layer (30 to $50 \mathrm{~m}$ ), where water temperature was $<10^{\circ} \mathrm{C}$, but it was absent above the pycnocline when temperatures were $>15^{\circ} \mathrm{C}$. Growth experiments revealed that $T$. laevis was able to grow at 0 to $10^{\circ} \mathrm{C}$ but not higher than $15^{\circ} \mathrm{C}$, indicating that its depth distribution mainly depended on temperature. High irradiances resulted in increased growth rates of $T$. laevis, with the highest rates of $0.50 \mathrm{~d}^{-1}$ at $150 \mu \mathrm{mol} \mathrm{m} \mathrm{s}^{-2}$. Using measured daily incident photosynthetically available radiation and in situ light attenuation, the growth rates of T. laevis at 30 and $50 \mathrm{~m}$ were calculated as 0.02 to 0.34 and -0.01 to $0.08 \mathrm{~d}^{-1}$, respectively. Distribution of $T$. laevis was strongly coupled with the occurrence of Oyashio water. The growth rate of T. laevis was lower than that of bolidophytes and diatoms, which are closely related to Parmales. Bloom forming diatoms in this region have higher growth rates and a broader temperature range $\left(0\right.$ to $\left.20^{\circ} \mathrm{C}\right)$ and, therefore, might be expected to dominate, but Parmales does manage to co-exist in this region, albeit at a moderate abundance compared to the diatoms.
\end{abstract}

KEY WORDS: Triparma laevis · Parmales · Vertical distribution · Growth characteristics · Oyashio region Resale or republication not permitted without written consent of the publisher

\section{INTRODUCTION}

Photosynthetic pico-eukaryotes $(\leq 3 \mu \mathrm{m})$ account for a large fraction of the biomass and primary production in marine ecosystems (Li 1994, Worden et al. 2004, Massana 2011). They are highly diverse, comprising several algal classes (Moon-van der Staay et al. 2001, Fuller et al. 2006, Vaulot et al. 2008). To understand how environmental factors affect their abundance and distribution as well as their ecological role in marine environments, an auto-ecological approach is necessary. However, there have been few auto-ecological studies combining measures of the abundance and distributions of pico-eukaryotic phytoplankton (Guillou et al. 1999b, Not et al. 2005) with growth characteristics determined from culture experiments (Timmermans et al. 2005, Lovejoy et al. 2007).

Parmales (Heterokonta) is a pico-sized eukaryotic marine phytoplankton group of small solitary cells that are surrounded by variously shaped silica plates (Booth \& Marchant 1987). They are widely distributed from tropical to polar waters (Nishida 1986, Takahashi et al. 1986, Booth \& Marchant 1987, Kosman et al. 1993), but they are more frequently reported from polar and sub-polar waters (Booth et al. 1981, 1982, Taniguchi et al. 1995, Komuro et al. 2005, Konno et al. 2007). Phylogenetic information 
was very limited until we managed to isolate and characterize a Parmales species, Triparma laevis, for the first time from the western North Pacific (Ichinomiya et al. 2011). The molecular phylogenetic analyses of SSU rDNA and the rbcL gene revealed that $T$. laevis belonged to the class Bolidophyceae, which are autotrophic pico-sized naked flagellates that lack silica structures and form a sister group of diatoms (Guillou et al. 1999a).

Some morphological features of Parmales, such as the number of plates or plate ornamentation, are species-specific (Booth \& Marchant 1987, Konno et al. 2007) and can only be observed with a scanning electron microscope (SEM). There have been some studies on abundance and distributions of Parmales species (Booth et al. 1980, Bravo-Sierra \& Hernández-Becerril 2003, Konno \& Jordan 2007), but only 2 studies have assessed growth characteristics using natural Parmales assemblages (Taniguchi et al. 1995, Ichinomiya et al. 2010) and no laboratory growth studies using cultures.

The Oyashio Current is located in the southwestern part of the western subarctic gyre in the North Pacific, flowing southwestward along the Kuril Islands and Hokkaido. The flow turns to the east off Honshu, becoming an extension flow. The area surrounded by the Oyashio Current and its extension is called the Oyashio region. The Oyashio region is colder and less-saline than the southern areas, i.e. the subtropical Kuroshio region and KuroshioOyashio transition region, where warm and cold eddies frequently detach from the Kuroshio and Oyashio regions, respectively (Itoh \& Yasuda 2010).

In the Oyashio region, a massive phytoplankton bloom (mainly diatoms) normally occurs in spring due to the nutrient-rich Oyashio water, but this terminates with the development of water stratification in summer (Isada et al. 2009). Parmales abundance increases from late spring, reaching a peak in summer-autumn in the Oyashio region ( $\mathrm{H}$. Hattori pers. comm.). However, the spatial distribution of Parmales across the Kuroshio-Oyashio transition region as well as the effects of hydrographic features are still unknown.

Triparma laevis belongs to the family Triparmaceae and is widely distributed in the North Pacific (Booth et al. 1982, Konno et al. 2007). In the Oyashio region, Ichinomiya et al. (2010) reported that this species was dominant (>90\%) among the Parmales assemblage in winter. The aim of the present study was to investigate what controls the vertical and horizontal distributions of T. laevis during summer by combining field data collected from across the Oyashio and Kuroshio-Oyashio transition regions with laboratory investigations of growth characteristics under varying temperatures and irradiances.

\section{MATERIALS AND METHODS}

\section{Field study}

Oceanographic observations were carried out from 7 to 22 July 2009 at 21 stations along the monitoring route 'A-line', which crosses the Oyashio and Kuroshio-Oyashio transition regions, off the south coast of Hokkaido, Japan, in the western North Pacific (Fig. 1A). Temperature and salinity were recorded with a CTD. Water samples for quantifying nutrients and chlorophyll a concentrations were collected with a bucket at the surface and Niskin sampling bottles from 7 depths from 10 to $100 \mathrm{~m}$ at every station of A1 to A4 and odd stations of A5 to A21. The samples for quantifying the abundance of Triparma laevis were collected from 7 depths at $0,10,20,30$, 50, 80 and $100 \mathrm{~m}$ at the same stations collected for nutrient analysis. At Stn A1, the water was collected at $90 \mathrm{~m}$ but not at $100 \mathrm{~m}$ because the depth at this station was $<100 \mathrm{~m}$. Aliquots $(500 \mathrm{ml})$ of water samples were fixed with acid Lugol's solution (final conc. $1 \%)$ and stored in a dark cold room $\left(5^{\circ} \mathrm{C}\right)$ until SEM analysis.

Incident photosynthetically available radiation (PAR, 400 to $700 \mathrm{~nm}$ ) above the sea surface was continuously measured on deck with a PAR sensor (ML-020P, EKO Instruments) and recorded in a data logger during the investigation period. During daytime sampling, vertical profiles of water PAR were obtained with a profiling reflectance radiometer PRR-600/610 (Biospherical Instruments). From the vertical profiles, attenuation coefficients $\left(k, \mathrm{~m}^{-1}\right)$ were determined to approximate the following equation:

$$
I_{z}=I_{0} \exp ^{-k z}
$$

where $I_{z}$ and $I_{0}$ are the irradiance at each depth $(z, \mathrm{~m})$ and the surface.

The concentrations of nitrate and silicate were determined with a TRAACS 800 autoanalyzer following the methods of Strickland \& Parsons (1972). For chlorophyll a analysis, $128 \mathrm{ml}$ aliquots of sea water were filtered using glass-fiber filters. The filters were soaked in N, N-dimethylformamide to extract chlorophyll a (Suzuki \& Ishimaru 1990) and determined with a Turner Designs fluorometer (10-AU-005). 

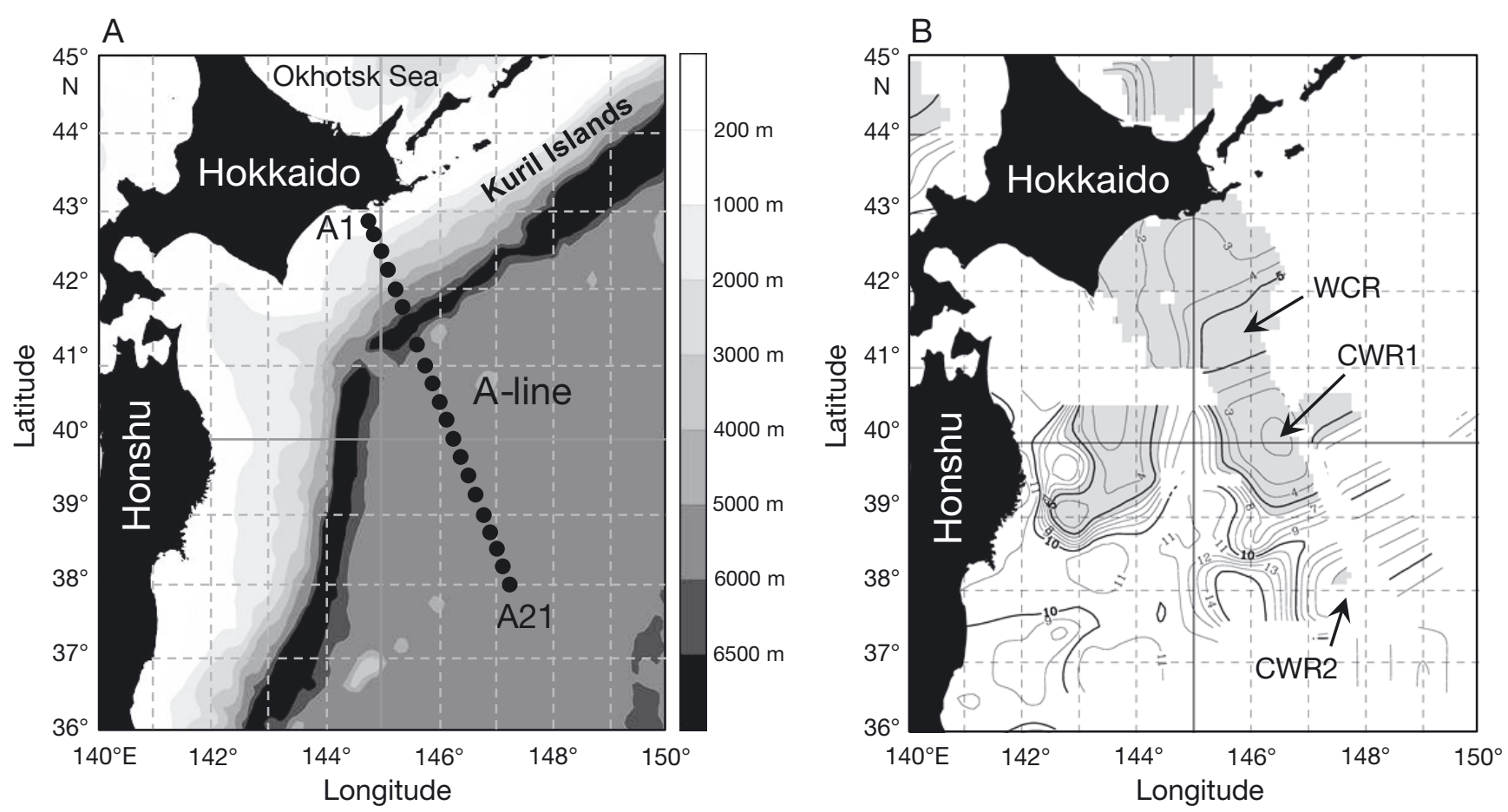

Fig. 1. (A) Sampling stations along the monitoring section A-line with the bottom topography and (B) the isotherms $\left({ }^{\circ} \mathrm{C}\right)$ at $100 \mathrm{~m}$ depth in July 2009. The temperature map was the color-modified one of the monthly publication by Tohoku National Fisheries Research Institute (http://tnfri.fra.affrc.go.jp/kaiyo/temp/data/200907_100.gif), which was drawn based on present observations and the other cooperative organizations' data. The area with temperature $<6^{\circ} \mathrm{C}$ at $100 \mathrm{~m}$ depth, which was regarded as the Oyashio region according to Kawai's (1972) indicator isotherm, is shaded, and the locations of a warm core ring (WCR) and the cold water regions (CWR1 and CWR2) along the A-line are denoted in panel B

The counting method for Triparma laevis was similar to that used by Booth at al. (1981) and Taniguchi et al. (1995). To quantify T. laevis abundance, $286 \mathrm{ml}$ aliquots of the fixed samples were filtered through $0.6 \mu \mathrm{m}$ polycarbonate filters using low vacuum pressure $(<10 \mathrm{kPa})$. The filters were air-dried at room temperature after desalting with a drop of Milli-Q water and mounted on the SEM stubs. All filters were coated with $\mathrm{Pt} / \mathrm{Pd}$ and examined with a SEM (Hitachi S-2550N). The numbers of T. laevis cells were randomly counted on the stubs at $4000 \times$ with a SEM in up to 400 fields, representing $0.38 \%$ of the mounted area of the stubs, with a detection

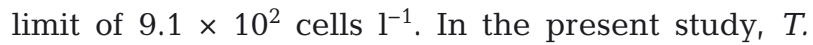
laevis, which has 3 subspecies and 1 form based on the existence of spines and cell wall ornamentation (Booth \& Marchant 1987, Kosman et al. 1993, Konno et al. 2007), was identified to species level. While almost all $T$. laevis cells were tightly covered with silica plates, a few broken plates were observed that were probably caused by vacuum pressure. This means that our counts may include some underestimation.

\section{Culture experiments in the laboratory}

Incubation experiments used the Triparma laevis strain that was isolated from the Oyashio region and deposited in the culture collection of the National Institute of Environmental Science in Japan under number NIES-2565 (Ichinomiya et al. 2011). It was maintained at $5^{\circ} \mathrm{C}$ under ca. $30 \mu \mathrm{mol} \mathrm{m} \mathrm{m}^{-2} \mathrm{~s}^{-1}$ with a $14 \mathrm{~h}$ light:10 $\mathrm{h}$ dark photoperiod in $\mathrm{f} / 2$ medium (Guillard \& Ryther 1962). Incubation experiments were conducted in triplicate at $0,5,10,15$ and $20^{\circ} \mathrm{C}$ at ca. $50 \mu \mathrm{mol} \mathrm{m} \mathrm{m}^{-2} \mathrm{~s}^{-1}$ by white LED (14 h light:10 h dark photoperiod), but T. laevis did not grow at 15 and $20^{\circ} \mathrm{C}$ in pre-cultured experiments. Experiments with 21 irradiance levels ( 3.7 to $200 \mu \mathrm{mol} \mathrm{m} \mathrm{m}^{-2} \mathrm{~s}^{-1}, 14 \mathrm{~h}$ light: $10 \mathrm{~h}$ dark photoperiod) were conducted at $5^{\circ} \mathrm{C}$.

Each experiment was carried out using a $70 \mathrm{ml}$ disposable sterilized culture bottle (Nunc). Inoculation was with a small amount of culture in the exponential growth phase at an initial cell concentration of $10^{3}$ cells $\mathrm{ml}^{-1}$. Incubation periods were 11 to $30 \mathrm{~d}$, with subsampling every day, except at low irradiance levels (3.7 to $9.8 \mu \mathrm{mol} \mathrm{m}^{-2} \mathrm{~s}^{-1}$ ) which were subsampled 
every other day. At each sampling time, a $1 \mathrm{ml}$ aliquot of algal culture was fixed with $10 \%$ paraformaldehyde (final conc. of $1 \%$ ) and immediately stored in liquid nitrogen. Cell concentrations of Triparma laevis were determined by an Epics XL (Beckman Coulter) flow cytometer equipped with a $15 \mathrm{~mW}$ laser at $488 \mathrm{~nm}$ excitation with the standard filter set-up for enumeration of picophytoplankton. Red fluorescence (>630 nm) from chlorophyll a was measured. Sample acquisition time was set for $5 \mathrm{~min}$ and ceased when 10000 events were counted. The analytical volume at a given time and flow rate was calibrated by running solutions of beads of known concentration. For a size check, internal standard beads of 1.0 and $2.0 \mu \mathrm{m}$ solid latex (Polysciences) were added to each sample. All data were analyzed using EXPO32 software (Beckman Coulter).

Growth rates $\left(\mu ; \mathrm{d}^{-1}\right)$ under varying temperature

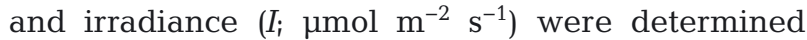
from the changes in cell number with time by logline regression during exponential growth. The maximum growth rate $\left(\mu_{\text {maxi }} \mathrm{d}^{-1}\right)$, half-saturation value

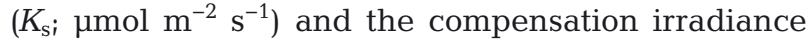
$\left(I_{\text {comp }} ; \mu \mathrm{mol} \mathrm{m}{ }^{-2} \mathrm{~s}^{-1}\right)$ under varying irradiance $\left(I_{i} \mu \mathrm{mol}\right.$ $\mathrm{m}^{-2} \mathrm{~s}^{-1}$ ) were calculated with the following equation of Yamaguchi et al. (1991), modifying that of Lederman \& Tett (1981):

$$
\mu=\mu_{\max } \times\left(I-I_{\text {comp }}\right) \frac{\mu_{\text {max }} \times\left(I-I_{\text {comp }}\right)}{\left(K_{\mathrm{s}}-I_{\text {comp }}\right)+\left(I-I_{\text {comp }}\right)}
$$

\section{RESULTS}

\section{Environmental conditions}

Horizontal temperature mapping at $100 \mathrm{~m}$ depth showed that the cold area $\left(<6^{\circ} \mathrm{C}\right)$, which roughly represented the Oyashio region (the precise distribution will be discussed in the next subsection), was distributed offshore from Hokkaido, reaching to nearly $39^{\circ} \mathrm{N}$ on the A-line (Fig. 1B). Therefore, the Kuroshio-Oyashio transition region was distributed south of $\sim 39^{\circ} \mathrm{N}$. In the Oyashio region, a slightly warmer water mass above $5^{\circ} \mathrm{C}$ at about 41 to $42^{\circ} \mathrm{N}$ and $146^{\circ} \mathrm{E}$ was judged to be a warm eddy that migrated northward from the Kuroshio-Oyashio transition region (see the time series of isotherms at http://tnfri.fra.affrc.go.jp/kaiyo/temp/temp.html). In the Kuroshio-Oyashio region, a cold water mass existed around $38^{\circ} \mathrm{N}$ on the A-line, which was a cold eddy that originated from the Oyashio region and was modified by the Kuroshio water.
Vertical stratification of water temperature and sigma-t was evident between 20 and $40 \mathrm{~m}$ at almost all stations (Fig. 2A,C). In the surface layer down to $20 \mathrm{~m}$, water temperature was $>10^{\circ} \mathrm{C}$, except for at Stns A1, A2 and A4. Low temperatures $\left(<5^{\circ} \mathrm{C}\right)$ were observed below 20 to $30 \mathrm{~m}$ at Stns A1, A2 and A4, $\sim 70 \mathrm{~m}$ at Stns A6 to A8 and $40 \mathrm{~m}$ at Stns A11 to A15. At the most southern station (Stn A21), relatively low temperatures $\left(<10^{\circ} \mathrm{C}\right)$ were observed below $50 \mathrm{~m}$, while water temperature was $>10^{\circ} \mathrm{C}$ down to $100 \mathrm{~m}$ at Stns A18 and A19. Changes in the depth distribution of salinity were similar to those of temperature, and cold waters were generally less saline. Salinity under 33.5 was observed at Stns A1 to A2, A4 and A11 to A15, except at the surface at some stations (Fig. 2B). Salinity above 33.5 occurred at Stns A3, A5 to A9 and A17 to A21.

Concentrations of nitrate and silicate were lower than 5 and $10 \mu \mathrm{M}$, respectively, down to $20 \mathrm{~m}$, except at Stns A1 to A4 (Fig. 2D,E). High concentrations ( $>10 \mu \mathrm{M}$ in nitrate and $>30 \mu \mathrm{M}$ in silicate), were observed below $50 \mathrm{~m}$ at Stns A2, A4 and A11 to A15. In general, concentrations of chlorophyll a were high at depths from 0 to $20 \mathrm{~m}$ at almost all stations, with no clear evidence of subsurface chlorophyll maxima (Fig. 2F). Concentrations of chlorophyll $a>1 \mu g \mathrm{l}^{-1}$ were observed at the surface at Stns A1, A5 to 11 and A15.

The daily incident PAR above the sea surface was in the range of 7.5 to $54.6 \mathrm{~mol} \mathrm{~m}^{-2} \mathrm{~d}^{-1}$ with an average of $34 \mathrm{~mol} \mathrm{~m}^{-2} \mathrm{~d}^{-1}$ during the investigation period (Table 1). Vertical profiles of PAR were measured at 4 stations, and $k$ was in the range of 0.109 to $0.150 \mathrm{~m}^{-1}$. From this $k$ value, the irradiances at 30 and $50 \mathrm{~m}$ were equivalent to 1.1 to 3.8 and 0.05 to $0.43 \%$ of the surface irradiance, respectively.

Table 1. Sampling date, daily incident photosynthetically available radiation (PAR) and attenuation coefficient

\begin{tabular}{|lccc|}
\hline $\begin{array}{l}\text { Date of } \\
\text { sampling } \\
\text { (2009) }\end{array}$ & $\begin{array}{c}\text { Sampling } \\
\text { location }\end{array}$ & $\begin{array}{c}\text { Daily } \\
\text { incident PAR } \\
\left(\mathrm{mol} \mathrm{m}^{-2} \mathrm{~d}^{-1}\right)\end{array}$ & $\begin{array}{c}\text { Attenuation } \\
\text { coefficient } \\
\left(\mathrm{m}^{-1}\right)\end{array}$ \\
\hline 12 July & & 30.7 & \\
13 July & A1 & & 0.138 \\
14 July & & 7.5 & \\
15 July & & 53.5 & 0.150 \\
16 July & A15 & 46.4 & 0.131 \\
17 July & A17 & 22.3 & \\
18 July & A19 & 24.7 & \\
19 July & & 54.6 & \\
20 July & & 36.9 & \\
21 July & & 34.6 & \\
Average & & & \\
\hline
\end{tabular}




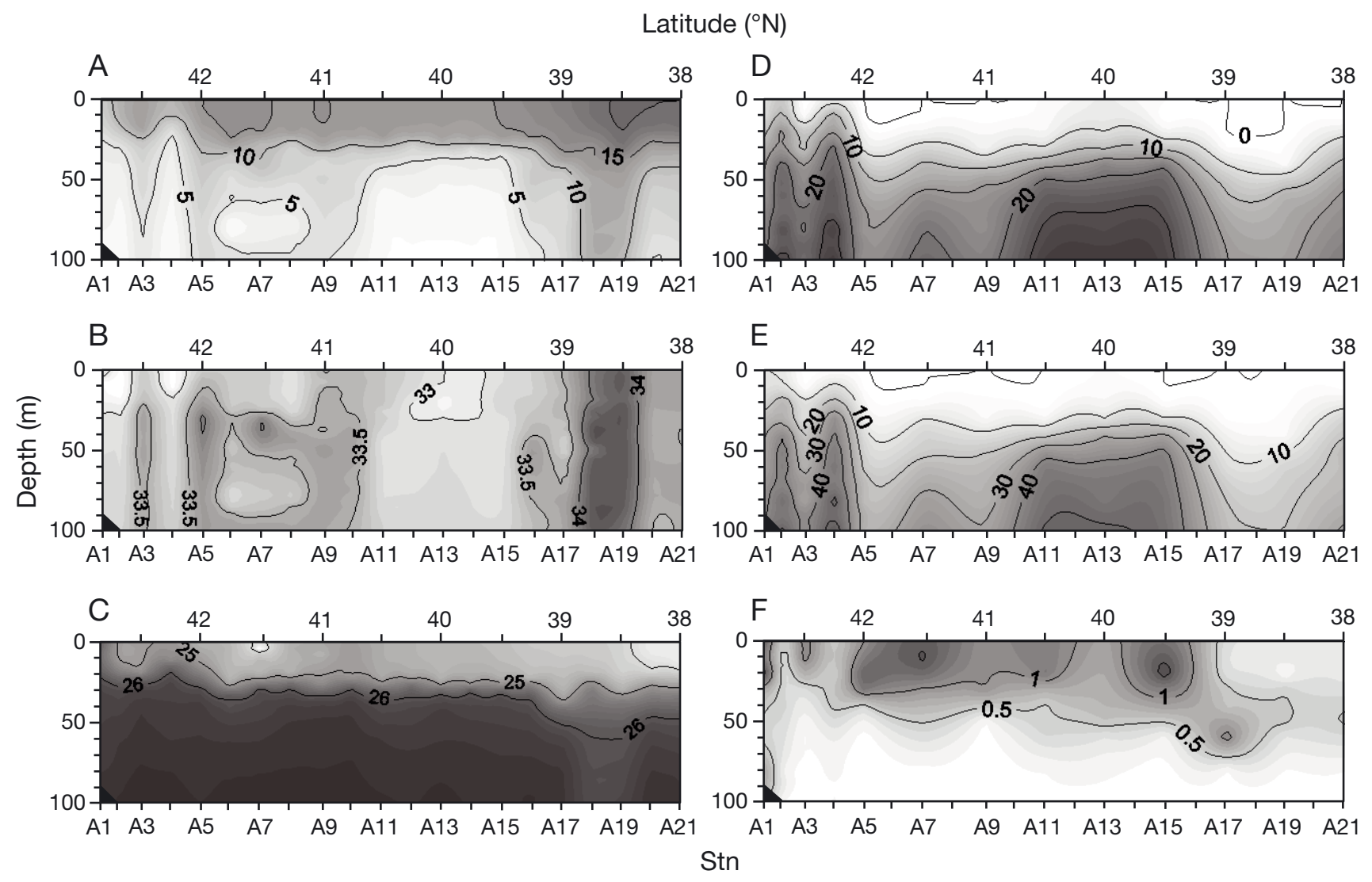

Fig. 2. Vertical distributions of $(\mathrm{A})$ temperature $\left({ }^{\circ} \mathrm{C}\right)$, (B) salinity, (C) sigma-t, (D) nitrate $(\mu \mathrm{M}),(\mathrm{E})$ silicate $(\mu \mathrm{M})$ and $(\mathrm{F})$ chlorophyll a concentration $\left(\mu \mathrm{g} \mathrm{l}^{-1}\right)$ in July 2009 along the A-line

\section{Vertical and regional distribution of Triparma laevis along the A-line}

Triparma laevis abundance was high $\left(>1.0 \times 10^{4}\right.$ cells $\mathrm{l}^{-1}$ ) in the subsurface layers of 30 to $50 \mathrm{~m}$ at almost all stations, but was low in the shallower layers down to $20 \mathrm{~m}$ and in the deeper layers below $80 \mathrm{~m}$ (Fig. 3). The highest abundance was $9.6 \times 10^{4}$ cells l$^{-1}$ at $50 \mathrm{~m}$ at Stn A15. At Stn A4, the maximum of $6.0 \times 10^{4}$ cells l$^{-1}$ was observed at $30 \mathrm{~m}$. At Stns A1, A17 and A19, the abundance

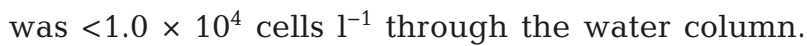
At Stn A21, a moderate abundance of $2.0 \times 10^{4}$ cells $\mathrm{l}^{-1}$ was recorded at $50 \mathrm{~m}$.

During the investigation period, temperature and salinity in the water column down to $100 \mathrm{~m}$ ranged from 1.7 to $20.5^{\circ} \mathrm{C}$ and from 32.8 to 34.4 , respectively (Fig. 4). Triparma laevis was found in waters with temperatures in the range of 1.7 to $14.5^{\circ} \mathrm{C}$ but not at $>15^{\circ} \mathrm{C}$ and occurred in a salinity range of 32.8 to 34.1 .

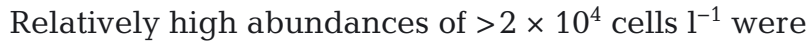
limited to waters with temperatures of 2.4 to $11.4^{\circ} \mathrm{C}$ and salinities of 33.0 to 33.9 .

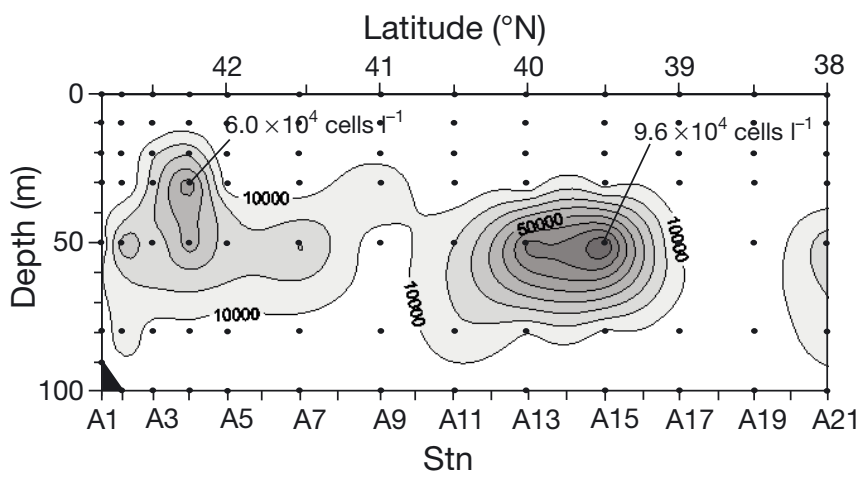

Fig. 3. Vertical distributions of abundance of Triparma laevis in July 2009 along the A-line

\section{Culture experiments}

In culture experiments, Triparma laevis showed exponential growth in batch culture over the range of 0 to $10^{\circ} \mathrm{C}$ (Fig. 5). The optimal temperature was $5^{\circ} \mathrm{C}$, with a growth rate of $0.35 \mathrm{~d}^{-1}$, and was significantly different from $0.22 \mathrm{~d}^{-1}$ at $0^{\circ} \mathrm{C}$ and $0.18 \mathrm{~d}^{-1}$ at $10^{\circ} \mathrm{C}$ at ca. $50 \mu \mathrm{mol} \mathrm{m} \mathrm{m}^{-2} \mathrm{~s}^{-1}$. 


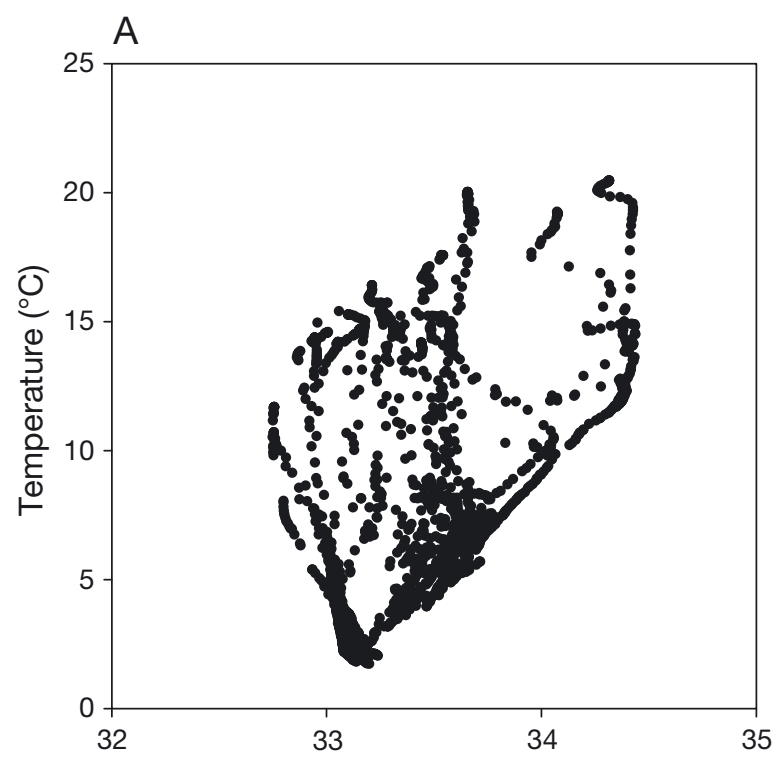

B

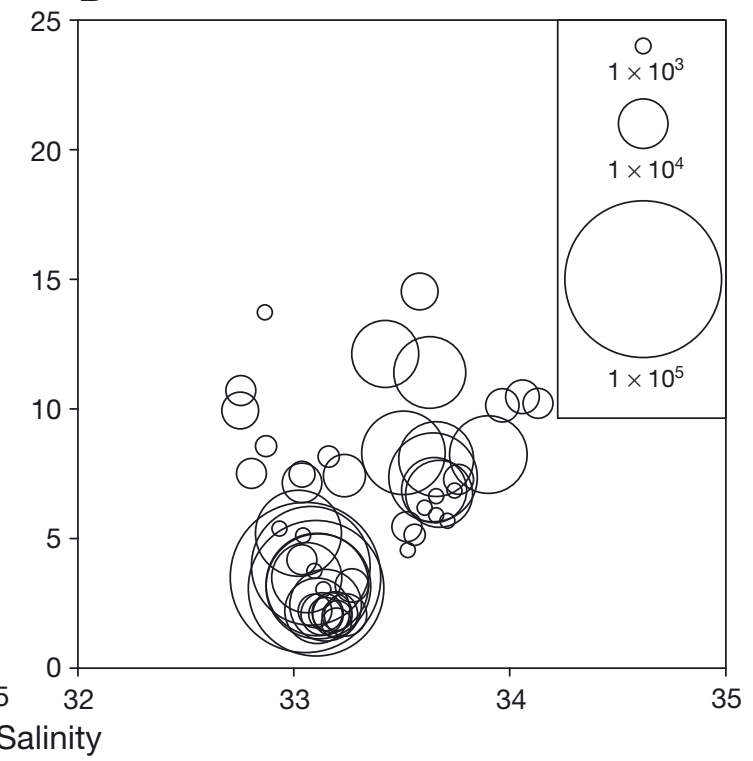

Fig. 4. (A) Temperature-salinity plots of $1 \mathrm{~m}$ intervals from the CTD data in the 0 to $100 \mathrm{~m}$ water columns and (B) the distribution of Triparma laevis (cells $\mathrm{l}^{-1}$ ) with water temperature and salinity

Higher irradiances resulted in increased growth rates at $5^{\circ} \mathrm{C}$ (Fig. 6). The highest growth rate was $0.50 \mathrm{~d}^{-1}$ at $150 \mu \mathrm{mol} \mathrm{m} \mathrm{m}^{-2} \mathrm{~s}^{-1}$ and the lowest was $0.08 \mathrm{~d}^{-1}$ at $3.8 \mu \mathrm{mol} \mathrm{m}{ }^{-2} \mathrm{~s}^{-1}$. The $\mu_{\max }, K_{\mathrm{s}}$ and $I_{\text {comp }}$ for irradiance were calculated as $0.51 \mathrm{~d}^{-1}, 21.1 \mu \mathrm{mol} \mathrm{m} \mathrm{m}^{-2} \mathrm{~s}^{-1}$ and $0.7 \mu \mathrm{mol} \mathrm{m}^{-2} \mathrm{~s}^{-1}\left(\mathrm{r}^{2}=0.97\right)$, respectively (Table 2$)$.

\section{DISCUSSION}

The depth distribution of Triparma laevis during summer across the Oyashio and Kuroshio-Oyashio

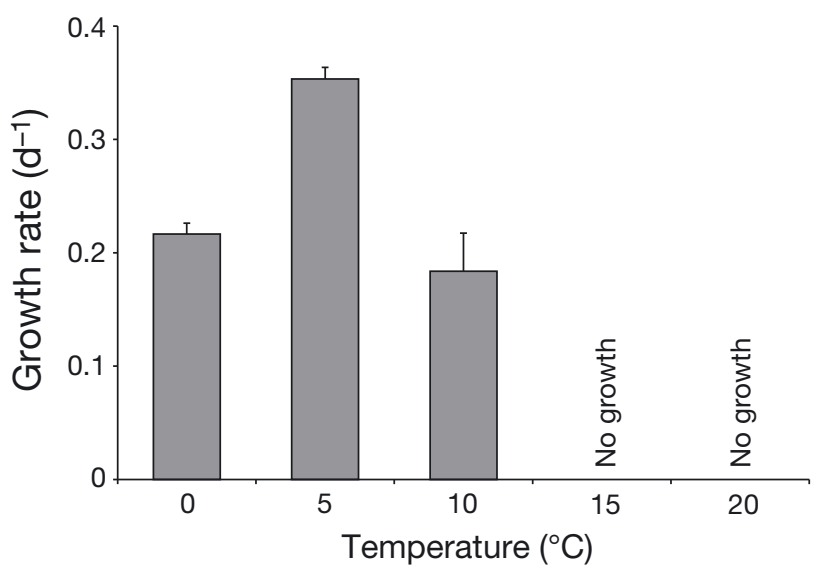

Fig. 5. Growth rates of Triparma laevis at $0,5,10,15$ and $20^{\circ} \mathrm{C}$ at ca. $50 \mu \mathrm{mol} \mathrm{m}{ }^{-2} \mathrm{~s}^{-1}(14 \mathrm{~h}$ light: $10 \mathrm{~h}$ dark photoperiod). T. laevis did not grow at 15 and $20^{\circ} \mathrm{C}$ in pre-cultural experiments. Bars are standard deviations $(\mathrm{n}=3)$ regions as well as the growth characteristics in culture are reported. T. laevis was mainly distributed in the subsurface layer at 30 to $50 \mathrm{~m}$, where water temperature was $<10^{\circ} \mathrm{C}$ (Figs. $2 \& 3$ ). T. laevis was less abundant from the surface down to $20 \mathrm{~m}$ and at temperatures $>15^{\circ} \mathrm{C}$ that were above the pycnocline. The depth distributions of $T$. laevis corresponded well with that predicted from the growth experiments for temperature (Fig. 5). T. laevis was able to grow at 0 to $10^{\circ} \mathrm{C}$ at ca. $50 \mu \mathrm{mol} \mathrm{m} \mathrm{m}^{-2} \mathrm{~s}^{-1}$ but not at $>15^{\circ} \mathrm{C}$. Optimum growth $\left(0.35 \mathrm{~d}^{-1}\right)$ was at $5^{\circ} \mathrm{C}$. Since this is the first report of a growth rate of a parmalean alga and is based on a single strain of $T$. laevis in culture, the present results may not represent growth rates of T. laevis populations in situ. However, the present result was consistent with a previous report that the natural Parmales assemblage was able to grow with rates of 0.29 to $0.38 \mathrm{~d}^{-1}$ at 5 to $12^{\circ} \mathrm{C}$ but not at $15^{\circ} \mathrm{C}$ on a shipboard incubation in the western North Pacific (Taniguchi et al. 1995). At Stn A4, the peak of T. lae-

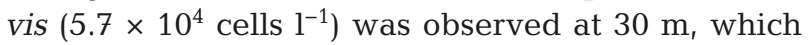
was shallower than at the other stations (Fig. 3). This was probably because the pycnocline was shallow and the temperature was $<10^{\circ} \mathrm{C}$ at depths below $10 \mathrm{~m}$ at this station (Fig. 2A,C). In general, the vertical distribution of $T$. laevis in summer was strictly limited to depths where the prevailing water temperature was suitable for its growth.

Light conditions also influenced the depth distribution of Triparma laevis (Fig. 6). During the investiga- 

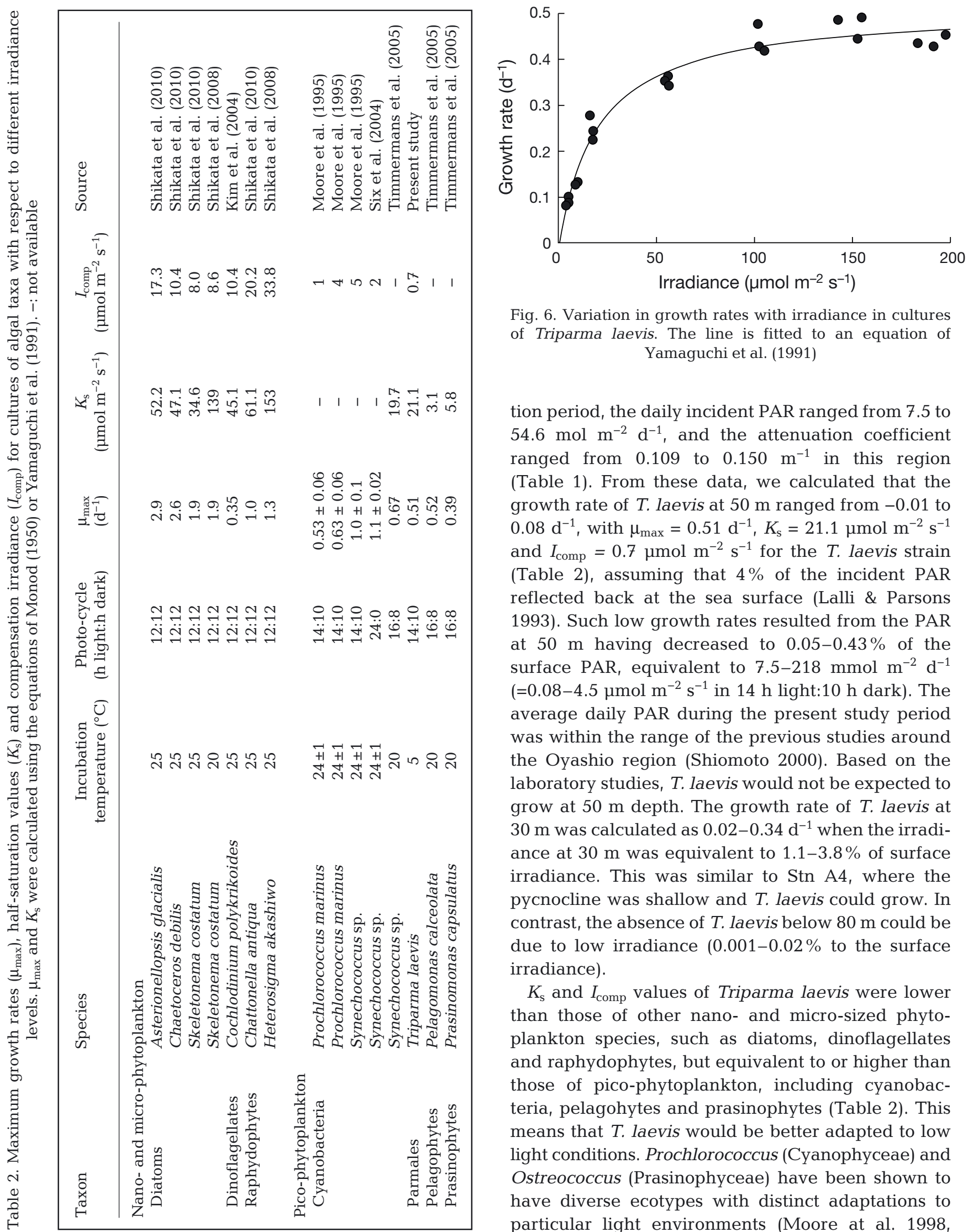

Fig. 6. Variation in growth rates with irradiance in cultures of Triparma laevis. The line is fitted to an equation of Yamaguchi et al. (1991)

tion period, the daily incident PAR ranged from 7.5 to $54.6 \mathrm{~mol} \mathrm{~m}^{-2} \mathrm{~d}^{-1}$, and the attenuation coefficient ranged from 0.109 to $0.150 \mathrm{~m}^{-1}$ in this region (Table 1). From these data, we calculated that the growth rate of $T$. laevis at $50 \mathrm{~m}$ ranged from -0.01 to $0.08 \mathrm{~d}^{-1}$, with $\mu_{\max }=0.51 \mathrm{~d}^{-1}, K_{\mathrm{s}}=21.1 \mu \mathrm{mol} \mathrm{m} \mathrm{m}^{-2} \mathrm{~s}^{-1}$ and $I_{\text {comp }}=0.7 \mu \mathrm{mol} \mathrm{m}{ }^{-2} \mathrm{~s}^{-1}$ for the T. laevis strain (Table 2), assuming that $4 \%$ of the incident PAR reflected back at the sea surface (Lalli \& Parsons 1993). Such low growth rates resulted from the PAR at $50 \mathrm{~m}$ having decreased to $0.05-0.43 \%$ of the surface PAR, equivalent to $7.5-218 \mathrm{mmol} \mathrm{m}^{-2} \mathrm{~d}^{-1}$ (=0.08-4.5 $\mu \mathrm{mol} \mathrm{m}{ }^{-2} \mathrm{~s}^{-1}$ in $14 \mathrm{~h}$ light: $10 \mathrm{~h}$ dark). The average daily PAR during the present study period was within the range of the previous studies around the Oyashio region (Shiomoto 2000). Based on the laboratory studies, $T$. laevis would not be expected to grow at $50 \mathrm{~m}$ depth. The growth rate of $T$. laevis at $30 \mathrm{~m}$ was calculated as $0.02-0.34 \mathrm{~d}^{-1}$ when the irradiance at $30 \mathrm{~m}$ was equivalent to $1.1-3.8 \%$ of surface irradiance. This was similar to Stn A4, where the pycnocline was shallow and T. laevis could grow. In contrast, the absence of $T$. laevis below $80 \mathrm{~m}$ could be due to low irradiance $(0.001-0.02 \%$ to the surface irradiance).

$K_{\mathrm{s}}$ and $I_{\text {comp }}$ values of Triparma laevis were lower than those of other nano- and micro-sized phytoplankton species, such as diatoms, dinoflagellates and raphydophytes, but equivalent to or higher than those of pico-phytoplankton, including cyanobacteria, pelagohytes and prasinophytes (Table 2). This means that $T$. laevis would be better adapted to low light conditions. Prochlorococcus (Cyanophyceae) and Ostreococcus (Prasinophyceae) have been shown to have diverse ecotypes with distinct adaptations to particular light environments (Moore at al. 1998, 
Rodríguez et al. 2005, Six et al. 2008). The strains of these algae isolated from deeper layers showed positive growth at low irradiance, while those isolated at the surface did not grow. More physiological information is needed from other species and strains of Parmales to fully understand their vertical distribution and light adaptation.

The spatial distribution of pico-plankton could be also affected by possible advection due to their limited cell mobility and low sinking rates (Hamilton et al. 2008). High abundance $\left(>5 \times 10^{4}\right.$ cells $\left.\mathrm{l}^{-1}\right)$ of Triparma laevis was observed at Stns A4 $\left(6.0 \times 10^{4}\right.$ cells

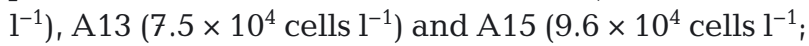
Fig. 3). According to Shimizu et al. (2009), the region north of the salinity front, with a salinity of 33.6 at 50 to $200 \mathrm{~m}$ depths, was defined as the Oyashio region. Based on their definition, Stns A1 to A4, A10 to A16, A20 and A21 were classified as in the Oyashio region. At Stn A21, relatively cold water $\left(<10^{\circ} \mathrm{C}\right)$ was observed below 50 m (Figs. 1 \& 2A). Such cold water has been considered to originate from the Oyashio water. This explains the moderate abundance of $T$. laevis at the southernmost station (Stn A21; Fig. 3).

The abundance of Triparma laevis was low at Stns A1 and A5 to A9, despite the fact that the water temperature seemed suitable for $T$. laevis growth at $<10^{\circ} \mathrm{C}$ throughout the water column (Figs. $2 \& 3$ ). A possible explanation for this decrease in abundance in low-temperature water may have been the different origin of the water masses. For example, from January to July, relatively low-salinity water $(<33.0)$, which mainly originated from the Okhotsk Sea, appeared along the Hokkaido coast (Kusaka et al. 2009, see their Fig. 3), and it was distinguished from the offshore Oyashio water by its salinity. At Stn A1, the low-salinity water $(<33.0)$ was distributed from the surface down to $20 \mathrm{~m}$ (Fig. 2B), and another Parmales species, Tetraparma pelagica, was dominant (data not shown). At Stns A5 to A9, in contrast, salinity under the pycnocline was higher $(>33.5)$ than in the surrounding areas (Fig. 2B), and it corresponded with the warm eddy position (41 to $42^{\circ} \mathrm{N}$ ), as described in the subsection 'Environmental conditions' (Fig. 1B). The water around Stns A5 to A9 must have been a mixture between the Oyashio and Kuroshio waters, which would explain the abundance of $T$. laevis. Our results indicated that the regional distribution of $T$. laevis was also strongly associated with the water currents and warm and cold water masses.

While Parmales is closely related to bolidophytes and diatoms, the growth characteristics of Parmales were different from these algae. Bolidomonas paci- fica, which have been isolated from the tropical equatorial Pacific and the Mediterranean Sea (Guillou et al. 1999b), prefers warm conditions and has a high growth rate of $0.91 \mathrm{~d}^{-1}$ at $20^{\circ} \mathrm{C}$ (Jacquet et al. 2001). Also, bloom-forming diatom species in the Oyashio region, such as Thalassiosira nordenskioeldii and Chaetoceros debilis, have much higher maximum growth rates $\left(>0.80 \mathrm{~d}^{-1}\right)$, with a broad temperature range of 0 to $20^{\circ} \mathrm{C}$, than that of Triparma laevis (Suzuki \& Takahashi 1995, A. Kuwata unpubl. data). In this region, small diatoms also form a dense bloom,

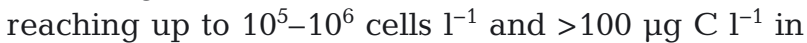
spring (Isada et al. 2009, Ichinomiya et al. 2010, Suzuki et al. 2011). This would be expected to give them an advantage throughout the euphotic zone in April to May in the Oyashio region. In contrast, T. laevis, with its lower maximum growth rate $\left(0.51 \mathrm{~d}^{-1}\right)$ and narrower temperature range $\left(0\right.$ to $10^{\circ} \mathrm{C}$; Fig. 5$)$, was restricted in its development in the subsurface

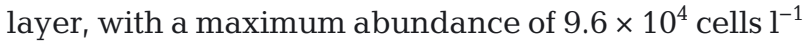
(Fig. 3). This probably explains the relatively low abundances of T. laevis compared to diatoms.

A previous study had hypothesized that Parmales, Bolidophyceae and diatoms had a common ancestor (Ichinomiya et al. 2011), but we need more information from comparative studies to fully understand their differentiation and evolution. Diatoms grow faster in the spring and are grazed by mesozooplankton, but they mostly sink out at the end of spring (Takahashi et al. 1990, 2008). In contrast, Parmales stay in suspension in the subsurface layer due to their small cell size (Fig. 3). Only a small fraction of Parmales sink out to below the euphotic zone in the northwestern Pacific (Komuro et al. 2005). These cells in the subsurface layer would likely be grazed by nano- and micro-sized heterotrophic protozoans (Taniguchi et al. 1995) and incorporated into the microbial loop rather than the grazing food chain. However, there is no information on their buoyancy regulation, sinking rates or grazing process. Many other aspects of their ecological role in marine ecosystems are still unclear and, therefore, we need to learn more about what controls their temporal and spatial distributions using combined laboratory and interdisciplinary field studies.

Acknowledgements. We thank Drs. D. Jewson and D. Vaulot for their critical reading of the manuscript. We are grateful to the captain and crew of the RV 'Wakataka-maru' for their cooperation with the sample collection. This study was partially supported by Japan Society for the Promotion of Science Grants-in-Aid for Scientific Research 22657027 (A.K.), 23370046 (A.K.), 19684016 (Y.S.) and 30601918 
(M.I.), the Canon Foundation (A.K.), JST, CREST (A.K.) and the MAFF research fund 'Evaluation, Adaptation and Mitigation of Global Warming in Agriculture, Forestry and Fisheries: Research and Development' (A.K. and Y.S.). Special thanks are extended to 3 anonymous reviewers for their critical reading of the manuscript.

\section{LITERATURE CITED}

Booth BC, Marchant HJ (1987) Parmales, a new order of marine chrysophytes, with descriptions of three new genera and seven new species. J Phycol 23:245-260

Booth BC, Lewin J, Norris RE (1980) Siliceous nanoplankton. I. Newly discovered cysts from the Gulf of Alaska. Mar Biol 58:205-209

Booth BC, Lewin J, Norris RE (1981) Silicified cysts in North Pacific nanoplankton. Biol Oceanogr 1:57-80

Booth BC, Lewin J, Norris RE (1982) Nanoplankton species predominant in the subarctic Pacific in May and June 1978. Deep-Sea Res A 29:185-200

Bravo-Sierra E, Hernández-Becerril DU (2003) Parmales (Chrysophyceae) from the Gulf of Tehuantepec, Mexico, including the description of a new species, Tetraparma insecta sp. nov., and a proposal to the taxonomy of the group. J Phycol 39:577-583

Fuller NJ, Campbell C, Allen DJ, Pitt FD and others (2006) Analysis of photosynthetic picoeukaryote diversity at open ocean sites in the Arabian Sea using a PCR biased towards marine algal plastids. Aquat Microb Ecol 43: 79-93

Guillard RRL, Ryther JH (1962) Studies of marine planktonic diatoms I. Cyclotella nana Hustedt and Detonula confervacea (Cleve) Gran. Can J Microbiol 8:229-239

Guillou L, Chrétiennot-Dinet MJ, Medlin LK, Claustre H, Loiseaux-de Goër S, Vaulot D (1999a) Bolidomonas: a new genus with two species belonging to a new algal class, the Bolidophyceae (Heterokonta). J Phycol 35: 368-381

Guillou L, Moon-van der Staay SY, Claustre H, Partensky F, Vaulot D (1999b) Diversity and abundance of Bolidophyceae (Heterokonta) in two oceanic regions. Appl Environ Microbiol 65:4528-4536

Hamilton AK, Lovejoy C, Galand PE, Ingram RG (2008) Water masses and biogeography of picoeukaryote assemblages in a cold hydrographically complex system. Limnol Oceanogr 53:922-935

Ichinomiya M, Gomi Y, Nakamachi M, Ota T, Kobari T (2010) Temporal patterns in silica deposition among siliceous plankton during the spring bloom in the Oyashio region. Deep-Sea Res II 57:1665-1670

Ichinomiya M, Yoshikawa S, Kamiya M, Ohki K, Takaichi S, Kuwata A (2011) Isolation and characterization of Parmales (Heterokonta/Heterokontophyta/Stramenopiles) from the Oyashio region, western North Pacific. J Phycol 47:144-151

Isada T, Kuwata A, Saito H, Ono T, Ishii M, YoshikawaInoue H, Suzuki K (2009) Photosynthetic features and primary productivity of phytoplankton in the Oyashio and Kuroshio-Oyashio transition regions of the northwest Pacific. J Plankton Res 31:1009-1025

Itoh S, Yasuda I (2010) Characteristics of mesoscale eddies in the Kuroshio-Oyashio Extension region detected from the distribution of the sea surface height anomaly. J Phys Oceanogr 40:1018-1034
Jacquet S, Partensky F, Lennon JF, Vaulot D (2001) Diel patterns of growth and division in marine picoplankton in culture. J Phycol 37:357-369

Kawai H (1972) Hydrography of the Kuroshio extension. In: Stommel H, Yoshida K (eds) Kuroshio. University of Tokyo Press, Tokyo, p 235-352

> Kim DI, Matsuyama Y, Nagasoe S, Yamaguchi M and others (2004) Effects of temperature, salinity and irradiance on the growth of the harmful red tide dinoflagellate Cochlodinium polykrikoides Margalef (Dinophyceae). J Plankton Res 26:61-66

Komuro C, Narita H, Imai K, Nojiri Y, Jordan RW (2005) Microplankton assemblages at Station KNOT in the subarctic western Pacific, 1999-2000. Deep-Sea Res II 52: 2206-2217

Konno S, Jordan RW (2007) An amended terminology for the Parmales (Chrysophyceae). Phycologia 46:612-616

Konno S, Ohira R, Komuro C, Harada N, Jordan RW (2007) Six new taxa of subarctic Parmales (Chrysophyceae). J Nanoplankton Res 29:108-128

Kosman CA, Thomsen HA, Østergaard JB (1993) Parmales (Chrysophyceae) from Mexican, Californian Baltic, Arctic and Antarctic waters with the description of new subspecies and several new forms. Phycologia 32:116-128

Kusaka A, Ono T, Azumaya T, Kasai H, Oguma S, Kawasaki Y, Hirakawa K (2009) Seasonal variations of oceanographic conditions in the continental shelf area off the eastern Pacific coast of Hokkaido, Japan. Oceanogr Jpn 18:135-156 (in Japanese with English abstract)

Lalli CM, Parsons TR (1993) Biological oceanography: an introduction. Pergamon Press, Oxford

Lederman TC, Tett P (1981) Problems in modeling the photosynthesis-light relationship for phytoplankton. Bot Mar 24:125-134

Li WKW (1994) Primary production of prochlorophytes, cyanobacteria, and eucaryotic ultraphytoplankton: measurements from flow cytometric sorting. Limnol Oceanogr 39:169-175

Lovejoy C, Vincent WF, Bonilla S, Roy S and others (2007) Distribution, phylogeny, and growth of cold-adapted picoprasinophytes in Arctic seas. J Phycol 43:78-89

Massana R (2011) Eukaryotic picoplankton in surface oceans. Annu Rev Microbiol 65:91-110

Monod J (1950) La technique de la culture continue. Théorie et applications. Ann Inst Pasteur Lille 79:390-410

> Moon-van der Staay SY, De Wachter R, Vaulot D (2001) Oceanic 18S rDNA sequences from picoplankton reveal unsuspected eukaryotic diversity. Nature 409:607-610

Moore LR, Goericke R, Chisholm SW (1995) Comparative physiology of Synechococcus and Prochlorococcus: influence of light and temperature on growth, pigments, fluorescence and absorptive properties. Mar Ecol Prog Ser 116:259-275

Moore LR, Rocap G, Chisholm SW (1998) Physiology and molecular phylogeny of coexisting Prochlorococcus ecotypes. Nature 393:464-467

Nishida S (1986) Nannoplankton flora in the Southern Ocean, with special reference to siliceous varieties. Mem Natl Inst Polar Res Tokyo Spec Issue 40:56-68

> Not F, Massana R, Latasa M, Marie D and others (2005) Late summer community composition and abundance of photosynthetic picoeukaryotes in Norwegian and Barents Seas. Limnol Oceanogr 50:1677-1686

Rodríguez F, Derelle E, Guillou L, Gall FL, Vaulot D, Moreau $\mathrm{H}$ (2005) Ecotype diversity in the marine picoeukaryote 
Ostreococcus (Chlorophyta, Prasinophyceae). Environ Microbiol 7:853-859

Shikata T, Nagasoe S, Matsubara T, Yoshikawa S and others (2008) Factors influencing the initiation of blooms of the raphidophyte Heterosigma akashiwo and the diatom Skeletonema costatum in a port in Japan. Limnol Oceanogr 53:2503-2518

Shikata T, Sakurada K, Jomoto Y, Onji M, Yoshida M, Ohwada K (2010) Effects of temperature, salinity and light irradiance on phytoplankton growth in the Yatsuishiro Sea. Bull Jpn Soc Sci Fish 76:34-45 (in Japanese with English abstract)

Shimizu Y, Takahashi K, Ito S, Kakehi S and others (2009) Transport of subarctic large copepods from the Oyashio area to the mixed water region by the coastal Oyashio intrusion. Fish Oceanogr 18:312-327

Shiomoto A (2000) Efficiency of water-column light utilization in the subarctic northwestern Pacific. Limnol Oceanogr 45:982-987

Six C, Thomas JC, Brahamsha B, Lemoine Y, Partensky F (2004) Photophysiology of the marine cyanobacterium Synechococcus sp. WH8102, a new model organism. Aquat Microb Ecol 35:17-29

Six C, Finkel ZV, Rodriguez F, Marie D, Partensky F, Campbell DA (2008) Contrasting photoacclimation costs in ecotypes of the marine eukaryotic picoplankter Ostreococcus. Limnol Oceanogr 53:255-265

Strickland JDH, Parsons TR (1972) A practical handboook of seawater analysis, 2nd edn. Bull Fish Res Board Can, Ottawa

Suzuki K, Kuwata A, Yoshie N, Shibata A, Kawanobe K, Saito H (2011) Population dynamics of phytoplankton, heterotrophic bacteria, and viruses during the spring bloom in the western subarctic Pacific. Deep-Sea Res I 58:575-589

Suzuki R, Ishimaru T (1990) An improved method for the

Editorial responsibility: Daniel Vaulot,

Roscoff, France determination of phytoplankton chlorophyll using N, Ndimethylformamide. J Oceanogr 46:190-194

Suzuki Y, Takahashi M (1995) Growth responses of several diatom species isolated from various environments to temperature. J Phycol 31:880-888

Takahashi E, Watanabe K, Satoh H (1986) Siliceous cysts from Kita-no-seto Strait, north of Syowa Station, Antarctica. Mem Natl Inst Polar Res Tokyo Spec Iss 40: 84-95

Takahashi K, Billings JD, Morgan JK (1990) Oceanic province: assessment from the time-series diatom fluxes in the northeastern Pacific. Limnol Oceanogr 35:154-165

Takahashi K, Kuwata A, Saito H, Ide K (2008) Grazing impact of the copepod community in the Oyashio region of the western subarctic Pacific Ocean. Prog Oceanogr 78:222-240

$>$ Taniguchi A, Suzuki T, Shimada S (1995) Growth characteristics of Parmales (Chrysophyceae) observed in bag cultures. Mar Biol 123:631-638

$>$ Timmermans KR, van der Wagt B, Veldhuis MJW, Maatman A, de Baar HJW (2005) Physiological responses of three species of marine pico-phytoplankton to ammonium, phosphate, iron and light limitation. J Sea Res 53: 109-120

$>$ Vaulot D, Eikrem W, Viprey M, Moreau H (2008) The diversity of small eukaryotic phytoplankton $(\leq 3 \mu \mathrm{m})$ in marine ecosystems. FEMS Microbiol Rev 32:795-820

> Worden AZ, Nolan JK, Palenik B (2004) Assessing the dynamics and ecology of marine picophytoplankton: the importance of the eukaryotic component. Limnol Oceanogr 49:168-179

> Yamaguchi M, Imai I, Honjo T (1991) Effect of temperature, salinity and irradiance on the growth rates of the noxious red tide flagellates Chattonella antiqua and C. marina (Raphidophyceae). Bull Jpn Soc Sci Fish 57:1277-1284 (in Japanese with English abstract)

Submitted: April 30, 2012; Accepted: October 28, 2012 Proofs received from author(s): December 10, 2012 